\title{
The heat is on: a new avenue to study brown fat formation in humans
}

\author{
Anthony Scimè* \\ Stem Cell Research Group, Faculty of Health, York University, Toronto, ON, Canada \\ *Correspondence: ascime@yorku.ca
}

\section{A commentary on}

Differentiation of human adipose-derived stem cells into "brite" (brown-in-white) adipocytes

by Pisani, D., Djedaini, M., Beranger, G. E., Elabd, C., Scheideler, M., Ailhaud, G., and Amri, E.-Z. (2011). Front. Endocrin. 2:87. doi: 10.3389/fendo.2011.00087

The ever increasing rates of obesity and its co-morbidities represent a significant worldwide health problem (Pijl, 2011). An effective and innovative strategy to reduce body weight would be to increase energy expenditure by altering the character of adipose tissue in the body. This approach does not merely aim to eliminate, white adipose tissue (WAT), our reservoirs of energy storage. Rather, its objective is to replace and/or add to WAT depots with highly energetic brown adipocytes. Although brown adipocytes are capable of synthesizing and storing triglyceride, they are functionally different from white adipocytes, playing an important role in heat production, blood triglyceride clearance, and glucose disposal (Cannon and Nedergaard, 2004; Nedergaard et al., 2010; Bartelt et al., 2011).

Both WAT and brown adipose tissue (BAT) are found in specific depots throughout the body (Cinti, 2005). The amount of active BAT found in the supraclavicular region of some human subjects, $\sim 63 \mathrm{~g}$, would be sufficient to metabolize an amount of energy equivalent to about $4 \mathrm{~kg}$ of WAT during the course of 1 year (Fruhbeck et al., 2009; Virtanen et al., 2009). Indeed, the weight loss potential of activated BAT is borne out of the estimation that as little as $50 \mathrm{~g}$ is sufficient to metabolize $20 \%$ of the daily energy needs of an individual (Rothwell and Stock, 1983).
Adipocytes are not restricted to their depot subtype, as brown adipocytes can also be found in WAT and vice versa (Cinti, 2005). Brown adipocytes found interspersed within WAT are known by a variety of names, including adaptive or recruitable fat cells, brown in white (brite) cells, or beige cells (Enerback, 2009; Ishibashi and Seale, 2010; Petrovic et al., 2010). Hence, increasing the numbers of brite cells within WAT depots represents an innovative approach to reduce weight gain.

In this report Pisani et al. (2011) characterize the formation of brite adipocytes in vitro from the trans-differentiation of human white adipocytes. For their experiments, they differentiated mesenchymal stem cells, which were isolated from WAT depots of human subjects, first into white adipocytes, and subsequently trans-differentiating them into brown adipocytes. These human multipotent adipose derived stem (hMADS) cells have the potential to differentiate into different mesodermal lineages not restricted to adipocytes, which include myoblasts and osteoblasts (Rodriguez et al., 2005; Elabd et al., 2007, 2009; Figure 1). The trans-differentiated white adipocytes formed brown adipocytes with enhanced uncoupling activity with the salient expression of the brown adipocyte marker UCP1. The brown phenotype was further authenticated by the enhanced mitochondriogenesis with increased levels of the fatty acid transporter CPT1B and cytochrome $c$ oxidase activity.

Pisani et al. (2011) found the brown adipocytes made from hMADS was dependent on agonist sustained activation of PPAR $\gamma$, chiefly rosiglitazone. As with brown cell formation in WAT depots of mice, the brown adipocytes that were formed did not appear to have originated from a skeletal muscle, Myf5-expressing progenitor (Seale et al.,
2008). However, unlike mouse brown adipocyte differentiation, brown conversion of hMADS cells was not stimulated by BMP7 treatment and was not modulated by activation of the Hedgehog pathway (Tseng et al., 2008; Pospisilik et al., 2010). Moreover, the brown adipocyte determination factor, PRDM16, was expressed at similar levels in both white and brown adipocytes (Seale et al., 2008). This is counter to the recent findings supporting the important involvement of PRDM16 in brite cell formation within the subcutaneous inguinal fat pads of mice (Seale et al., 2011). This discrepancy in hMADS cells may be species specific. However, it does not rule out the possibility that PRDM16 might be controlled at a different level (i.e. protein or activity) in hMADS cells that is not manifested by the differentiation approach used by Pisani et al. (2011).

Although, Pisani et al. (2011) provide compelling evidence for transdifferentiation of white into brown adipocytes in vitro, there are other potential avenues to recruit brown adipocytes within WAT depots. Notably, newly formed brown adipocytes in WAT could be derived from: a common white preadipocyte, a WAT specific brown preadipocyte, or by the mobilization of uncommitted MSCs into a brown adipocyte lineage (Scime et al., 2005; Figure 1). These alternative avenues to recruit brown adipocytes may depend on a particular physiological state. hMADS cells will now make it possible to study these different potentialities in vitro.

Overall, the work of Pisani et al. provides an important approach to understand the in vitro mechanisms for human brown adipocyte development in WAT. Unlocking the pathways and cues required for brown cell activation in humans will lead to promising avenues for drug therapies against obesity. 


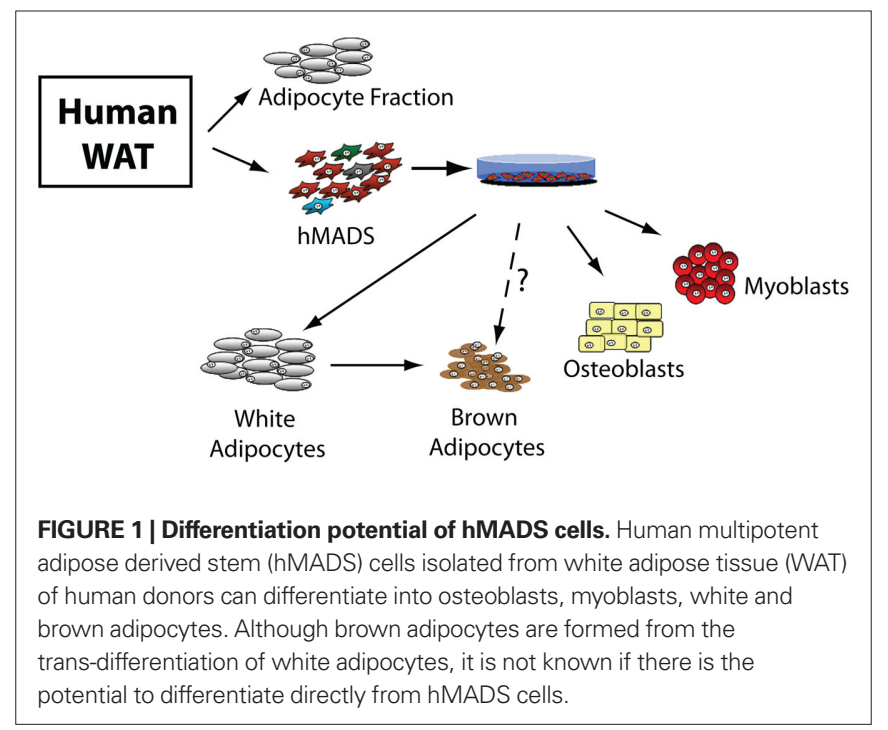

\section{REFERENCES}

Bartelt, A., Bruns, O. T., Reimer, R., Hohenberg, H., Ittrich, H., Peldschus, K., Kaul, M. G., Tromsdorf, U. I., Weller, H., Waurisch, C., Eychmuller, A., Gordts, P. L., Rinninger, F., Bruegelmann, K., Freund, B., Nielsen, P., Merkel, M., and Heeren, J. (2011). Brown adipose tissue activity controls triglyceride clearance. Nat. Med. 17, 200-205.

Cannon, B., and Nedergaard, J. (2004). Brown adipose tissue: function and physiological significance. Physiol. Rev. 84, 277-359.

Cinti, S. (2005). The adipose organ. Prostaglandins Leukot. Essent. Fatty Acids 73, 9-15.

Elabd, C., Chiellini, C., Carmona, M., Galitzky, J., Cochet, O., Petersen, R., Penicaud, L., Kristiansen, K., Bouloumie, A., Casteilla, L., Dani, C., Ailhaud, G., and Amri, E. Z. (2009). Human multipotent adiposederived stem cells differentiate into functional brown adipocytes. Stem Cells 27, 2753-2760.

Elabd, C., Chiellini, C., Massoudi, A., Cochet, O., Zaragosi, L. E., Trojani, C., Michiels, J. F., Weiss, P., Carle, G., Rochet, N., Dechesne, C. A., Ailhaud, G., Dani, C., and Amri, E.Z. (2007). Human adipose tissue-derived multipotent stem cells differentiate in vitro and in vivo into osteocyte-like cells. Biochem. Biophys. Res. Commun. 361, 342-348.

Enerback, S. (2009). The origins of brown adipose tissue. N. Engl. J. Med. 360, 2021-2023.

Fruhbeck, G., Becerril, S., Sainz, N., Garrastachu, P., and Garcia-Velloso, M. J. (2009). BAT: a new target for human obesity? Trends Pharmacol. Sci. 30, 387-396.

Ishibashi, J., and Seale, P. (2010). Medicine. Beige can be slimming. Science 328, 1113-1114.

Nedergaard, J., Bengtsson, T., and Cannon, B. (2010). Three years with adult human brown adipose tissue. Ann. N. Y. Acad. Sci. 1212, E20-E36.

Petrovic, N., Walden, T. B., Shabalina, I. G., Timmons, J. A., Cannon, B., and Nedergaard, J. (2010). Chronic peroxisome proliferator-activated receptor gamma (PPARgamma) activation of epididymally derived white adipocyte cultures reveals a population of thermogenically competent, UCP1-containing adipocytes molecularly distinct from classic brown adipocytes. J. Biol. Chem. 285, 7153-7164.

Pijl, H. (2011). Obesity: evolution of a symptom of affluence. Neth. J. Med. 69, 159-166.

Pisani, D., Djedaini, M., Beranger, G. E., Elabd, C., Scheideler, M., Ailhaud, G., and Amri, E. -Z. (2011). Differentiation of human adiposederived stem cells into "brite" (brown-in-white) adipocytes. Front. Endocrin. 2:87. doi: 10.3389/ fendo.2011.000879

Pospisilik, J. A., Schramek, D., Schnidar, H., Cronin, S. J., Nehme, N. T., Zhang, X., Knauf, C., Cani, P. D., Aumayr, K., Todoric, J., Bayer, M., Haschemi, A., Puviindran, V., Tar, K., Orthofer, M., Neely, G. G., Dietzl, G., Manoukian, A., Funovics, M., Prager, G., Wagner, O., Ferrandon, D., Aberger, F., Hui, C. C., Esterbauer, H., and Penninger,J.M. (2010). Drosophila genome-wide obesity screen reveals hedgehog as a determinant of brown versus white adipose cell fate. Cell 140, 148-160.

Rodriguez, A. M., Pisani, D., Dechesne, C. A., Turc-Carel, C., Kurzenne, J. Y., Wdziekonski, B., Villageois, A., Bagnis, C., Breittmayer, J. P., Groux, H., Ailhaud, G., and Dani, C. (2005). Transplantation of a multipotent cell population from human adipose tissue induces dystrophin expression in the immunocompetent $\mathrm{mdx}$ mouse. J. Exp. Med. 201, 1397-1405.

Rothwell,N.J., and Stock,M.J.(1983).Luxuskonsumption, diet-induced thermogenesis and brown fat: the case in favour. Clin. Sci. 64, 19-23.

Scime, A., Grenier, G., Huh, M. S., Gillespie, M. A., Bevilacqua, L., Harper, M. E., and Rudnicki, M. A. (2005). Rb and p107 regulate preadipocyte differentiation into white versus brown fat through repression of PGC-1alpha. Cell Metab. 2, 283-295.

Seale, P., Bjork, B., Yang, W., Kajimura, S., Chin, S., Kuang, S., Scime, A., Devarakonda, S., Conroe, H. M., Erdjument-Bromage, H., Tempst, P., Rudnicki, M. A., Beier, D. R., and Spiegelman, B. M. (2008). PRDM16 controls a brown fat/skeletal muscle switch. Nature 454, 961-967.

Seale, P., Conroe, H. M., Estall, J., Kajimura, S., Frontini, A., Ishibashi, J., Cohen, P., Cinti, S., and Spiegelman, B. M. (2011). Prdm16 determines the thermogenic program of subcutaneous white adipose tissue in mice. J. Clin. Invest. 121, 96-105.

Tseng, Y. H., Kokkotou, E., Schulz, T. J., Huang, T. L., Winnay, J. N., Taniguchi, C. M., Tran, T. T., Suzuki, R., Espinoza, D. O., Yamamoto, Y., Ahrens, M. J., Dudley, A. T., Norris, A. W., Kulkarni, R. N., and Kahn, C. R. (2008). New role of bone morphogenetic protein 7 in brown adipogenesis and energy expenditure. Nature 454, 1000-1004.

Virtanen, K. A., Lidell, M. E., Orava, J., Heglind, M., Westergren, R., Niemi, T., Taittonen, M., Laine, J., Savisto, N. J., Enerback, S., and Nuutila, P. (2009). Functional brown adipose tissue in healthy adults. N. Engl. J. Med. 360, 1518-1525.

Received: 22 November 2011; accepted: 27 December 2011; published online: 13 January 2012.

Citation: Scimè A (2012) The heat is on: a new avenue to study brown fat formation in humans. Front. Endocrin. 2:118. doi: 10.3389/fendo.2011.00118

This article was submitted to Frontiers in Cellular Endocrinology, a specialty of Frontiers in Endocrinology. Copyright (c) 2012 Scimè. This is an open-access article distributed under the terms of the Creative Commons Attribution Non Commercial License, which permits noncommercial use, distribution, and reproduction in other forums, provided the original authors and source are credited. 